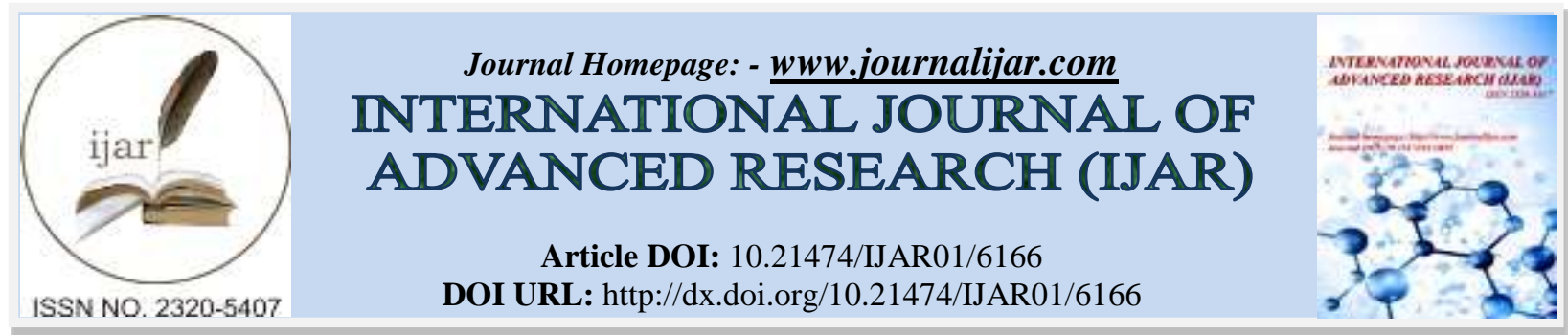

RESEARCH ARTICLE

\title{
THE EVALUATION OF THE PROGRAM OF TNI TEAM UP TO BUILD VILLAGES (TMMD) IN DKI JAKARTA AND THE SURROUNDING REGIONS.
}

Tahan Samuel Lumban Toruan.

Deputy of Secretary General of the Indonesian National Resilience Council on National Systems.

\section{Manuscript Info}

Manuscript History

Received: 25 October 2017

Final Accepted: 27 November 2017

Published: December 2017

Keywords:-

Evaluation, Program, Effectiveness,

Cipp.

\section{Abstract}

This research aimed to evaluate the effectiveness of the implementation of the Program of The Indonesia National Army (TNI) Team Up to Build Village (TMMD) as the civic mission of TNI in order to identify the rate of togetherness between Indonesian National Army (TNI) Personnels and the citizen the the capital city of Jakarta, and the surrounding regions. This research applied qualitative method with CIPP evaluation model that consists of four evaluation components, those are: (1) context; (2) input; (3) process; and (4) product. All the data was collected through interview, observation, questionnaire, group discussion, and documentation study. The scoring towards the evaluation result is divided into three levels of category: high/effective, medium/effective enough, and low/less effective. This category was applied in accordance with the comparison of goal standard in every evaluation stage upon either the physical or non-physical activity in the field. These activities were obtained based on the summary which was sum up using Case Order Effect Matrix. The findings present that the efficacy of the program "Indonesia National Army (TNI) Team Up to Build Village" in enhancing the togetherness between Indonesian National Army Personnels and the citizen was considered as "medium". Thus, the program "Indonesia National Army (TNI) Team Up to Build Village" in Jakarta and the surrounding regions in 2012 period was effective enough to enhance the togetherness between TNI and the citizens.

Copy Right, IJAR, 2017,. All rights reserved.

\section{Introduction:-}

History told that the teamwork between TNI-Citizens had resulted into great achievements to secure the sovereignity of country and support the development. One of the attempts to preserve or even improve the relationship between TNI-Citizens was through the implementation of the program "Indonesia National Army (TNI) Team Up to Build Village" or known as "TNI Manunggal Membangun Desa" abbreviated as TMMD. This program is one of the "civic missions" of TNI to improve the togetherness between TNI and citizens under the motto of "Together with People, TNI is strong". The attitude of TNI which always struggle to work together and get close to the people is the reflection of the philosophy of "winning the hearts and minds of people". This is such an essential philosophy in assisting the army, including TNI, during executing their duties and fuctions. 
TMMD program is conducted as physical program (such as the construction or maintenence of: infrastructure, public facilities, religious buildings; citizen's house, etc) and also non-physical program (socialization about law, health, nationalism, nationality, entrepreneirship training, etc). Both programs above aimed to improve the unity between TNI and the citizens and accelerate the development in rural, remote, unfortunate, isolated, frontier, slu m, and other areas effected by natural disaster. This is and integrated program that involves multiple sectors, such as TNI, Ministry/ Non-Ministry Institution, Local Government, and other national components that have involved in the program since the initial foundation in 1981 up to the moment.

Knowing that the program have conducted for more that 3 (three) decades, there should have been some improvements in the unity between TNI and Citizens based on several indicators, like: increasing trust from the citizens to TNI; improving the citizen's awareness in the social life; enhancing civic and citizenship knowledge; raising the spirit of unity, mutual cooperation, as well as improving the citizen's active participation in developing their areas.

Unfortunately, despite of the long run of program of TMMD, especially in area of DKI Jakarta and the surroundings regions, a study showed that there are disparities in the execution. Stakeholder who mostly involved are the low class society, while those who are in middle to high class citizens who live pretty far from the TMMD location nearly never participate in the program.

Furthermore, there are still many cases of brawl either between group of communities of citizens or between groups of students, increasing amount of drug abuse cases, and the disobedience attitude of the society and their lack of awareness towards the traffic policy. There are also many people who do not care about the environment cleanliness and safety. In Jakarta, the existance of slum areas with people who live in a very unfortunate situation seems to be an everyday sight. And knowing that all the problems above are actually the target of TMMD program, to eradicate or at least decrease the cases through physical and non-physical ation, is something to be considered about.

The orientation to conduct the program "Indonesia National Army (TNI) Team Up to Build Village" (TMMD) is to create sphere of struggle; instrument of struggle; condition of struggle and the unity of TNI-Citizens in order to assist the Government to improve the nation's prosperity through either physical or nonphysical development that could also establish condusive situation to realize safety stability in the nation (Indonesian National Army Headquoters, 2012).

The main target of TMMD are: (a) the growth and development of common vision and mission among the government staffs and social leaders in an integrated manner to empower the society along with the environment; (b) the development of the life and prosperity of the society to build a prosperous and independent nations that can overcome any threats possible; (c) the development of social awareness of the society that reflected from their attitude in obeying the law and national discipline during their social activities; (d) the improvement of society's civic and citizenship knowledge regarding to their every field of profession; and (e) the growth of the spirit of togetherness, mutual cooperation, sense of belonging, and active participation in developing the areas in order to achieve strong unity in the society and unity between TNI-Citizen (Indonesian National Army Headquoters, 2012).

Therefore, the implementation of TMMD program need to be evaluated in the sense of its effect towards the spirit of togetherness, mutual cooperation, sense of belonging, and the active participation of the society. This way, the effectiveness of the program in Jakarta Capital Special Region Province and the surrounding regions to improve the togetherness between TNI-Citizens can be identified. Since this program has been conducted for a long period of time, this research will only focus on 2012-2013 period of the program to ease the study.

\section{Review of Literature:-}

According to C.H Weiss (1998), evaluation is a systematic scoring system for a certain program or policy based on the statutory explisit and implisit standard to fix a program or policy. Fort, Martinez, Mukhopadhyay (2001) in Donna M. Mertens defined evaluation as a gradual scoring towards the relevance, performance, and either expected or not expected effect from a project according to the objective that has been set. Based on James C. McDavid, et.al (2005) evaluation can be considered as a structurized process that can produce and synthesis information to reduce the uncertainty about an enacted program of policy for the stakeholders. Kristi D, Menix (2007) added that evaluation is a scoring process that requires criteria or expected outcomes. Song and Nick Letch (2012) stated that evaluation is a process used to identify, measure, and value an object in a certain context. 
Regarding to "program", Joan L. Herman et.al. (1987) in Farida said that program is anything that someone tries to do to create a particular result or influence. Smith (1989) in John M. Owen defined a program as a set of plannedactivities, conducted to create specific changes that can be identified by the public. Similarly, James C.Mc David et.al (2005) added that a program is an integrated set of activities to achieve one or several goals. Kathryn E Newcomer et.al. (2010) explained that program is a set of resources and ativities that aims to achieve communal goal directed by a manager of management team. Meanwhile according to Thomas L. Wheelen \& J.David Hunger (2012), program is the statement from activities or stages required to create a program planning using action-based strategy.

Furthermore, regarding to "program evaluation", Robson (2002) in Sylvia A. Metcalfe et.al. explicated that program evaluation intended to determne the effect and the result from a certain event, intervension, policy, practice, service or innovasion that is implemented in every program. According to James C.Mc David, et.al. (2005) program evaluation is a combination and variation of theory and practice that is applied for a large scale either in public, nonprofit, and in private organization sector that aims to gain information for the future planning, designing, and implementation. On the other hand, Huey-Tsyh Chen (2005) defined program evaluation as the implementation of evaluation approach, implementation approach, and knowledge approach in a systematic manner to judge and improve the planning, implementation, and the effectiveness of the programs. Kathryn E Newcomer (2010) that program evaluation provides the process and instrument that can be applied by any agency to gain valid, reliable, and credible data to solve any problems related to the public sector performance and non-profit programs.

Addditionally, Richard L. Daft (2000) stated that effectiveness is about how well an organization manage to reach their expected goals. James McDavid (2006) said that effectiveness is about how consistent the result towards the expected goals is.

Relationship according to AS Hornby (2005) is the way in which two people, groups or countries behave towards each other or deal with each other. The in which two or more things are connected.

This research implemented CIPP evaluation model (context, input, process, product) that is developed by Stufflebeam, et.al. (1967) in Ohio State University. Stufflebeam developed a framework by providing four different kinds of decision, those are: (1) context evaluation to analyze the needs to be managed by one or several programs than can help to determine the goals of the program; (2) input evaluation helps to determine the available resources, the strategies or alternatives that must be considered and decide which strategy has the best potential to fulfill the needs to facilitize the designed procedure of the program; (3) process evaluation functions during the decision making stage by raising several questions like "what hinders the implementation?" and "which parts need to be revised?"and (4) product evaluation helps during the preparation for the new cycle by analyzing what are the results gain and what should be done after the program has been conducted.

Below is the flowchart of CIPP designed by Stufflebeam. It portrays the role of CIPP model in fixing the program (Daniel L.Stufflebeam \& Anthony J.Shinkfield (2007) of "TNI Team-Up to Build Villages" (TMMD) period of year 2012 in Jakarta Capital Special Region Province and the surrounding regions in order to improve the unity between TNI-Citizens. 
Figure-1:- Flowchart Of Cipp Evaluation Role In Improving TMMD Program System

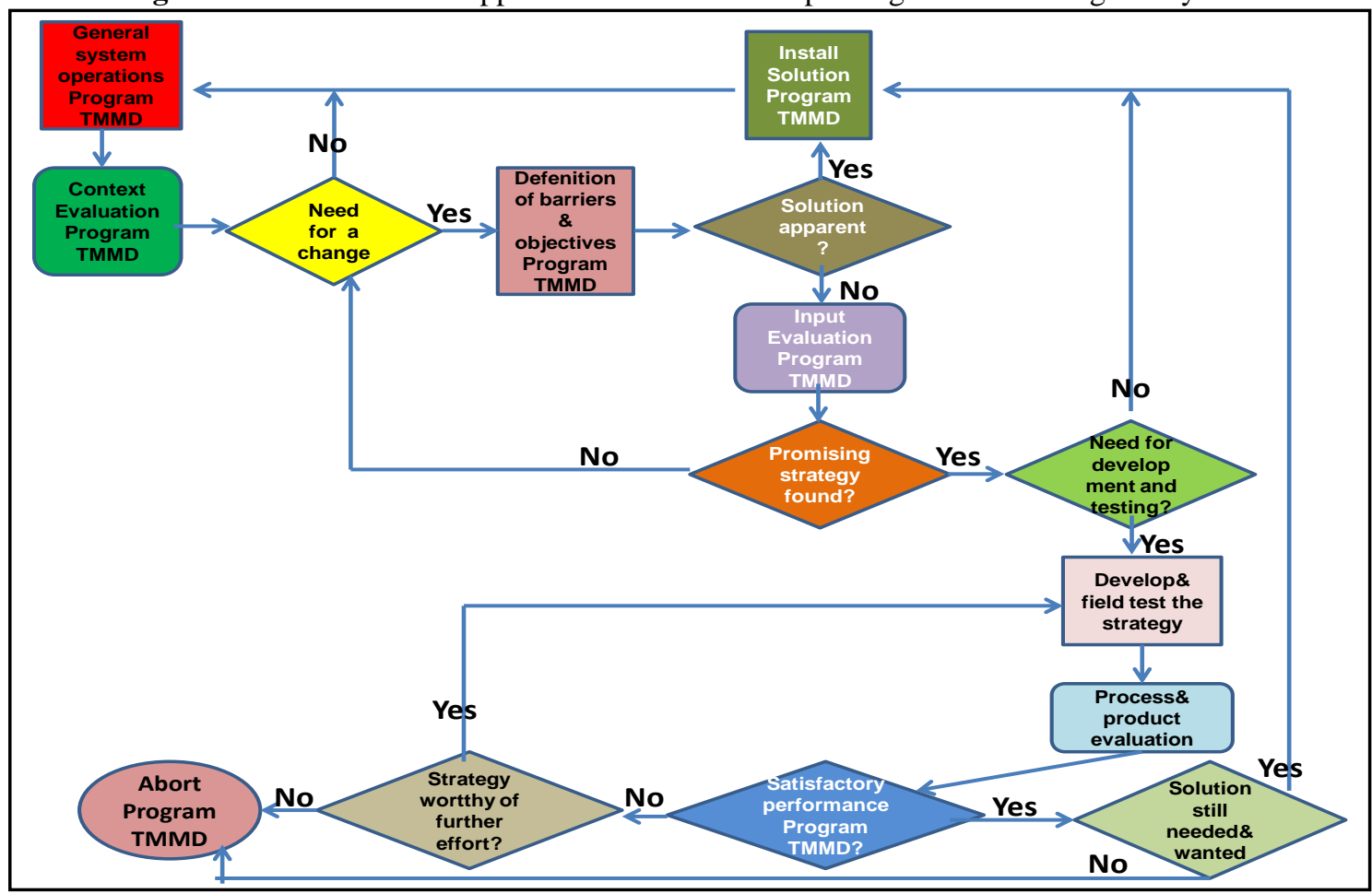

All in all, this study about "TNI Team-Up to build Villages" in period of year 2012 meant to evaluate about: (a) need assessment in formulating the objective and the target of this program, especial in the stage of planning; (b) the preparation, accuracy, and the completeness of the activities program based on the program planning, procedure and mechanism, structure of organization, monitoring and control, support from the resources ( such as: human resources, facilities, and financial fund) according to the goals and target of the program in input stage; (c) the program implementation that includes program planning, procedure and mechanism, structure of organization, monitoring and control, support from the resources ( such as: human resources, facilities, and financial fund) during the stage of process; and (d) The result of the program implementation in the sence of closeness between TNI members and the citizen in Jakarta Capital Special Region Province and the surrounding regions at the stage of product.

\section{Research Method:-}

The area of Jakarta Capital Special Region Province and the surrounding regions were chosen for TMMD evaluation program because of the heterogeneity and the dynamic of the people living in the area. Since the main target of TMMD program are rural, remote, unfortunate, isolated, frontier, slum, and other areas affected by natural disaster (Indonesian National Army Headquoters, 2012), Jakarta is a suitable target for the program since Jakarta is the second dirtiest city in Indonesia (Zulfi Suhendra, 2013). Let alone poverty is still spreaded around Jakarta. Moreover, the number of poverty keeps increase year by year. In period of January to Septeber 2013, the number of poor family had reached to 375.000 persons, it was 9.000 more than the number obtained in 2012 which was approximately 366.000 persons. Based on this data, it is calculated that the number of poor family in Jakarta is equal to $3.75 \%$ out of the total amount of people in Jakarta, 10.8 million (Musni Umar,2014).

This research took place in the locations where TMMD program was located during period of year 2012 in Jakarta Capital Special Region Province (North Jakarta Municipality, South Jakarta Municipality, East Jakarta Municipality and West Jakarta Municipality) and the surrounding regions (Bekasi District, Bogor District, Depok District and Tangerang District)

The study through the documentation analysis is began in the Jaya Military Commando Base in Jakarta as the as the Control of Operational Activity (PKO) if the program TNI Team Up to Build Villages in Jakarta Capital Special Region Province and its Surrounding Region as well as the Indonesian Military Headquoters as the Party in Charge 
for the Operational (PJO) of the TMMD program. The respondents of the study consist of three levels: (a) in the level of man in charge on the process of TMMD program consist of the Commander of TNI represented by the Territorial Assistant of Commander of TNI and the Head of Staff of Army that represented by the Territorial Assistant of Head of Staff of Army. (b) In the level of executor of TMMD Program, it consists of Commander of Military of Jaya Region represented by the Territorial Assistant of the Commander of Military of Jaya Region; Commandant of Region Command 051/WKT; Commandant of Region Command 052/WKR; Commandant of Military District Command of Northern Jakarta, Commandant of Military District Command of Southern Jakarta; Commandant of Military District Command of Depok, Commandant of Military District Command of Bekasi; Commandant of Military District Command of Tangerang; Commandant of Company Equivalent Unit of Depok Task Force Unit; Commandant of Company Equivalent Unit of Bekasi Task Force Unit; Commandant of Company Equivalent Unit of Northern Jakarta Task Force Unit; Commandant of Company Equivalent Unit of Southern Jakarta Task Force Unit. (c) While in the level of receiver for the TMMD Program, there are the Head of Social, Women and Family Planning Empowerment of Jakarta Capital Special Region Province, City Government of: Bekasi; Depok; Tangerang; Northern Jakarta; and Southern Jakarta, Regency Government of: Tangerang; and Bogor, Government of Sub-District of: Blendung; Benda; Jatiluhur; Jati Asih; Sukmajaya; Bojonggede; Semper Timur; Tanjung Barat; Jagakarsa; Cilincing Sub-District, and Village Head of Ragajaya, all the society from the six Sub-District/Village mentioned above, such as: Head of Civil Association, Head of Neighborhood Association, the religious figure, cultural figure, youth icon, and the common citizens. This activity is done in 6 (six) months from the June 2014 to December 2014.

This study used the evaluative research method to test the successfulness of the TMMD program on 2012 period in the Jakarta Capital Special Region Province and the Surrounding Region as well as to test the effectiveness of a policy in improving the closeness between TNI and Society to be used as the strategic recommendation about the success of the TMMD program in the future in the Jakarta Capital Special Region Province and its Surrounding Region.

In this study, the technique for data collecting used is through the documentation process from the written sources, interview, observation, questionnaires and Focused Group Discussion (FGD). The technique for data analysis used in evaluating the TMMD program in the Jakarta Capital Special Region Province and its Surrounding Region is the statistics descriptive data analysis with the model developed by Matthew B. Miles and A. Michael Huberman (1994) which cover: (a) data collection; (b) data reduction; (c) data display; and (d) conclusion drawing/verification,

According to the description and the definition of the program, the criteria of evaluation is determined to be used as the parameter of effectiveness of the implementation of TMMD period of year 2012 program in the Jakarta Capital Special Region Province and its Surrounding Region. These criteria becomes the standard to measure the accomplishment of the TMMD program period of year 2012 in the Jakarta Capital Special Region Province and its Surrounding Region. Meanwhile, those criteria are composed in the in the form of a table which cover the phase of evaluation (context, input, process and output), aspect that is evaluated in every component as well as the standard/criteria of evaluation that is expected is shown in the table below.

Table:- Criteria for The Evaluation Program of TMMD Period of year 2012 in Jakarta Capital Special Region Province and its Surrounding

\begin{tabular}{|c|c|c|}
\hline $\begin{array}{l}\text { EVALUATION } \\
\text { COMPONENT }\end{array}$ & $\begin{array}{c}\text { EVALUATED } \\
\text { ASPECTS }\end{array}$ & CRITERIA/EVALUATION STANDARD \\
\hline $\begin{array}{l}\text { Evaluation context } \\
\text { - } \quad \text { Formulation of goal } \\
\text { and target of program }\end{array}$ & $\begin{array}{l}\text { Goal and target of } \\
\text { TMMD Program }\end{array}$ & $\begin{array}{l}\text { 1. The formulation for the goal of the program is clear, } \\
\text { realistic, useful, can be achieved as well as has gone } \\
\text { through the need analysis process and referring to the } \\
\text { evaluation result of the previous program. } \\
\text { 2. The formulation for the target of the program is clear, } \\
\text { realistic, significant, measurable, achievable, and } \\
\text { useful. }\end{array}$ \\
\hline $\begin{array}{l}\text { Evaluation Input } \\
\text { - Preparation for the } \\
\text { activity of the } \\
\text { program }\end{array}$ & $\begin{array}{l}\text { 2. Mechanism of the } \\
\text { procedure }\end{array}$ & $\begin{array}{l}\text { 1. The activity plan has been composed in detail, and is } \\
\text { relevant, achievable and specific. } \\
\text { 2. The mechanism of the procedure is clear, detailed, } \\
\text { effective, and relevant. }\end{array}$ \\
\hline
\end{tabular}




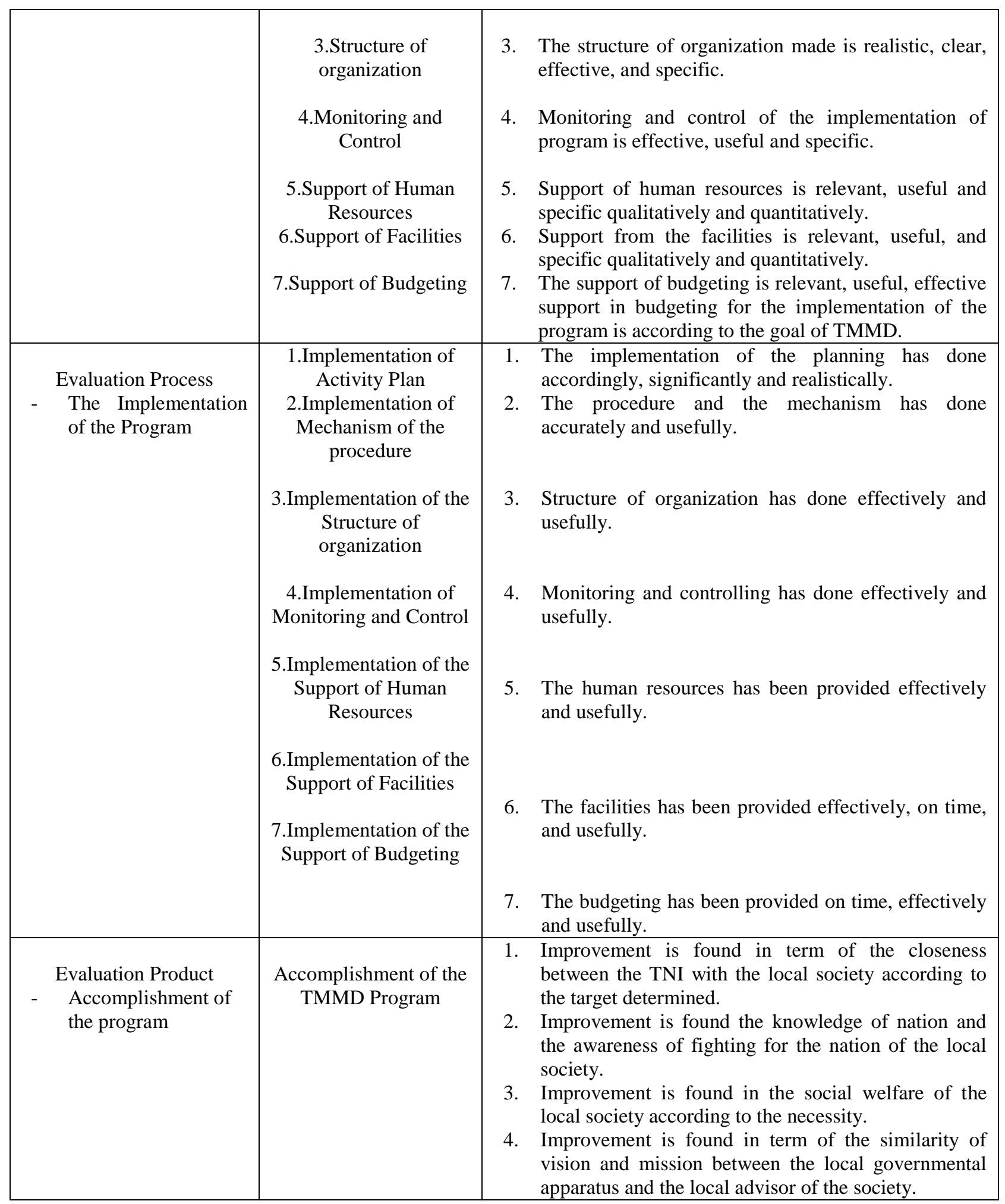

After that, for the necessity of the qualitative analysis, then the criteria are transferred and arranged into score according to a certain grade. Generally, there are two kinds of criteria, qualitative and quantitative criteria. Both criteria are each differentiated into two: criteria made with consideration and without any consideration (Suharsimi Arikunto \& Cepi Safruddin Abdul Jabar, 2008). For the need of evaluation using the qualitative criteria arranged with no consideration, it requires the calculation of how many indicators are in the components that fulfill the 
requirement (Suharsimi Arikunto \& Cepi Safruddin Abdul Jabar, 2008). For the scoring scale, this study used three choices of categories: high, which means effective; moderate, which means fairly effective; and low, which means less effective (Stephen Isaac \& William B. Michael, 1983). In order to support the methodology of the study, then the study procedure is designed as the figure below.

Figure-2:- The Procedure of Study of The TMMD Program Period of year 2012 in The Jakarta Capital Special Region Province and its Surrounding Region

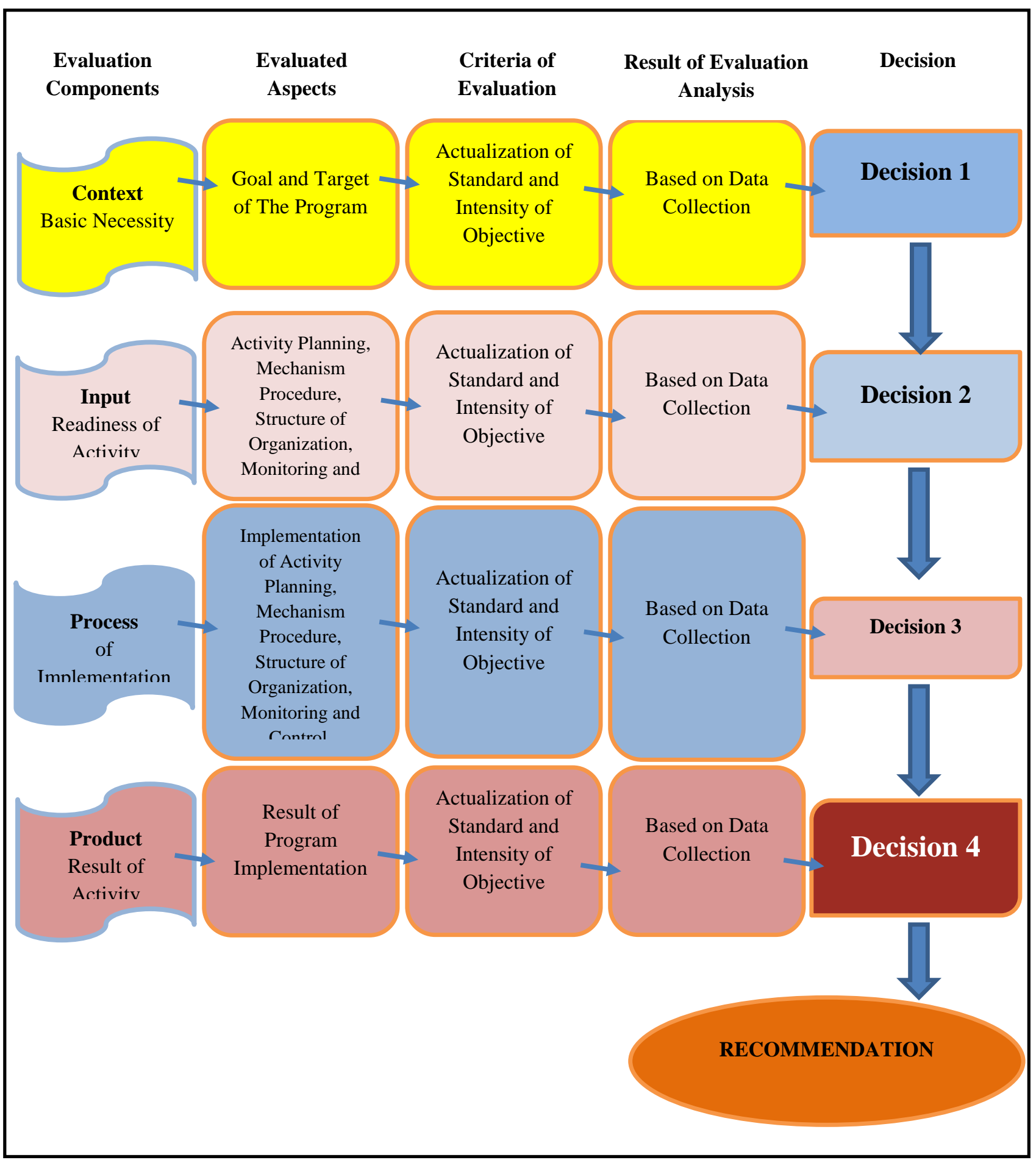




\section{Findings and Discussion:- \\ Planning Components (Context):-}

The effectiveness of goal and target accomplishment on the TMMD TA Program of 2012 in the Jakarta Capital Special Regon Province and the Surrounding Region that based on the scoring of the need analysis and the result of the evaluation from the previous TMMD Program is in category of "moderate", which in other word is "fairly effective". This is due to the accomplishment of the goal has not fully adjusted with the geographical characteristics and the demography of the Jakarta Capital Special Regon Province and the Surrounding Region, especially in the physical activity program. In addition, the determining of target done by the committee of TMMD period of year 2012 in the Jakarta Capital Special Regon Province and the Surrounding Region tend to go monotonous and having less variety from time to time.

\section{Components of Preparation (Input):-}

The effectiveness of formulation, accuracy, completeness and the readiness from the planning of the activity program, procedure and mechanism, organization structure, human resources support, and support of budgeting in promoting the goal and target accomplishment of the TMMD program in the Jakarta Capital Special Regon Province and its Surrounding Region was in the category of "moderate" or in other word is "fairly effective". This is because that in planning the activity specifically in determining the target located in the sub-urban still become the difficulty because the target in this location is commonly, its development, programmed by the City/Regency Government.

In the same case, the determination of the mechanism procedure of the program of activity has not designed specifically according to the characteristics of the Jakarta Capital Special Regon Province and it Surrounding Region. The structure of organization of the TMMD program is seen to be prioritizing the participant from the internal party of the TNI and is not much of involving the Civilian Institution such as the Technical Agencies of Provincial as well as Regency/City Government according to their competence to help holding the TMMD program.

In relation with the support upon the human resources, the response of the society is good, yet only in places where the physical activity done. While the response of the society live relatively for the target location of the physical activity showed lack of enthusiasm in participating. In the same case, the society, in the physical activity, are commonly unable to participate in the TMMD program especially those permanent employees. The same thing with the society of middle-upper class also not involved in the program since the physical activity commonly held in the urban area even in the slum one.

The budgeting support in the TMMD program of 2012 period in the Jakarta Capital Special Regon Province and its Surrounding Region also has not been effective for the budgeting that become the duty of the Region Governmental in providing this is unable to accommodate the many regions that needs to be the target for the physical activity. This becomes a harder situation since the budgeting support from the TMMD in the Jakarta Capital Special Regon Province has not been added from time to time, while the price of all the materials increased every year.

The monitoring control and the support provision in facilities in the TMMD program in the Jakarta Capital Special Regon Province and its Surrounding Region is in the category scoring of "high" or in other word "effective". This is because that in the monitoring and control, it is based on the hierarchy and the command structure of the TMMD organization that regularly contributing significantly in monitoring the practice of the TMMD program.

\section{Component of Implementation:-}

Effectiveness and usefulness of the physical and non-physical activities as well as the mix of the two in the TMMD program of 2012 period upon the attempt to gain more closeness between the TNI and the people of the Jakarta Capital Special Regon Province and its Surrounding Region is in the category of "moderate" on other word is "fairly effective". This can be seen from the activities that are physical, where the togetherness and cooperation has built between the TNI and society in the target location of the TMMD program. Then, there are attitude and willingness of the society to deliver the problem found in their environment to the apparatus of local TNI. Furthermore, the physical activity also help the local government in building infrastructure that the benefit of the result can be felt directly by the people.

However, the practice of physical activity still indicate that the involvement of society mostly came from those who are from the "low class society" especially the people that do not have a permanent employment and are the people whose places are target of the physical activity. On the opposite, the people from the "middle class society" and the 
people who live relatively far from the target location of physical activity has shown lack of involvement in the program. The volume of activity is also seen to be less broad and there should be much more to do so that the physical activity still can only classified as not optimal. Besides, the time for the physical activity that is relatively short in the schedule is seen less effective in creating the closeness between the TNI and the people.

The result from non-physical activity is still showing a less optimal result in increasing the independence of the people considering that the materials in the non-physical activity is tend to be monotonous, has not much of variation, especially in facing the development of environment that is very dynamic specifically in the Jakarta Capital Special Regon Province and its Surrounding Region. Then, the implementation of non-physical activity is not effective either because the frequent non-synchronized schedule and activity with the people living there. The non-physical activity will only be participated by many locals only if it is done also while giving them free groceries or free entertainment. In the same thing, the non-physical activity is not yet effective in helping the local government in educating about the safety and security of society. This can be seen from the phenomena of frequent cases of locals involved in the case of drugs abuse, brawl between locals and the ignorance of traffic rules by the locals.

\section{Result Accomplishment Component (Product):-}

In the aspect of benefit and effectiveness of TMMD program, in physical activity found some improvement in the closeness between TNI and Society that is in the category of "high" or on other words "effective". That condition can happen considering that the result of physical activity of TMMD program in the form of infrastructure building not only that the benefit can be felt directly by the locals but also because it is really needed and it is not available so far.

However, also found some aspect of it that is categorized as "moderate" or in other word "fairly effective". That can happen considering that there are still many people and its environment that is still untouched by the TMMD program. That happened because the wide area of coverage and the huge number of people living in Jakarta Capital Special Regon Province and its Surrounding Region that need it. The effectiveness of practice of the physical activity is still frequently hindered by the time of the program because there are a lot of people that are busy working so that they feel difficult in moving them for the program even though basically the society are enthusiastic upon it.

In the aspect of benefit and effectiveness, the TMMD program, the non-physical, upon the improvement of closeness between TNI and Society, is in the category of score of "high" or it also means "effective". That can happened if the non-physical activity is followed with the free groceries and free entertainment so that it may be followed by more locals.

On the opposite, some of it are also categorized as "moderate" or in other word "fairly effective". That condition can be seen from the response from the society upon the non-physical activity that is less enthusiast due to the nonphysical materials that is tend no be monotonous, having less variations when facing the development in the environment that is dynamic specifically in the Jakarta Capital Special Regon Province and its Surrounding Region.

\section{Conclusion and Suggestion:- \\ Conclusion:-}

Referring to the result of the research and the discussion mentioned above then the effectiveness of the progress of the TMMD Program of the 2012 period in the Jakarta Capital Special Regon Province, generally, in the aspect of physical and non-physical is fairly effective in creating the closeness between TNI and Society including in helping the local or regional government to build their respective regions. However, for the society who directly feel the benefit of the physical work in the TMMD program, it seemed that it give an effective in improving the closeness between the TNI and Society whether in the aspect of physical as well as non-physical activity.

Hence, the TMMD program can be continued considering that this program is highly needed by the most society, especially the society that live in an untouched location by the national development as well as the regional development. In this case, it needs corrections in the aspects of the program activity that is less effective so that the implementation of the program can be more effective and useful.

\section{Suggestion:-}

In order to improve the effectiveness of TMMD program in the Jakarta Capital Special Regon Province and its Surrounding Region, then some points of recommendations are proposed: 


\section{In the aspect of context components:-}

(a) an activity needs to be designed that is more creative and innovative that can involve participation of the society widely and optimally especially the working society, the middle class society as well as the society outside the location of physical activity of TMMD program that is adjusted with the dynamic and he characteristics of social life in the Capital City of the Nation and its Surrounding Region. (b) Improvement of budget allocation needs to be expanded in term of volume and the range of target along with time that is longer so that it becomes more effective in improving the closeness of TNI and Society;

\section{In the aspect of process component:-}

(a) a more creative and innovative needed to be designed that can improve the participation of society widely and optimally especially the society who are working, middle-class as well as the society outside of the target location of the physical activity in the TMMD program that is adjusted with the dynamic and the characteristics of social life in the Capital City of Nation and its Surrounding Region. (b) in determining the target and the arrangement of schedule of activity, coordination needed to be improved to be more intensive with the other parties from the local government in order to accommodate the importance of locals as the accomplishment goal for the TMMD program that can be more optimal. (c) The optimal involvement of the big family of The Indonesian National Army other youth organization to optimize the result from the TMMD program; and

\section{In the aspect of product component:-}

(a) a more creative and innovative needed to be designed that can improve the independence and the economic empowerment of the society in order to improve the prosperity of the people accordingly to the dynamic and the characteristics of social life in the Capital City of Nation and its Surrounding Region. (b) Intensive and wide socialization needed to be done about the activities in TMMD program especially the goal and target of the TMMD program long before the day TMMD program started, such as through meeting with the public figure, religious leader/figure, cultural icon, and youth figure as well as through other mass media. Also, (c) evaluation needed to be done in the TMMD program comprehensively based on the fact and condition objectively in the field every year to be able be used as the material of planning for the next year of period of the TMMD program.

\section{References:-}

1. Arikunto, Suharsimi and Jabar, Cepi Safruddin Abdul (2008). Evaluation of Education Program: Practical Theoretical Guidance for Students and Education Practitioners. Jakarta: PT. Bumi Aksara.p. 4

2. Chen, Huey Tsyh.(2005). Practical Program Evaluation: Assessing and Improving Planning, Implementation and Effectiveness. Thousand Oaks: Sage Publications.p.3

3. David, James C.Mc and Hawthorn, Laura R.L.(2005). Key Concepts And Issues In Program Evaluation And Performance Measurement. Chapter 1, London: Sage Publications,Inc.p.3

4. Fort, Martinez, Mukhopadhyay (2001) in Mertens, Donna M. (2005). Research and Evaluation in Education and Psychology: Integrating Diversity with Quantitative, qualitative and Mixed Methods. Second Edition, Thousand Oaks: Sage Publications,Inc.p.47

5. Hornby, AS (2005). Oxford Advanced Learner's Dictionary of Current English.Oxford: Oxford University Press.p. 1277

6. Isaac, Stephen \& Michael, Wiliam B. (1983). Handbook in Research and Evaluation (San Diego California: Edits Publisher.p. 12

7. Joan L. Herman et.al (1987) in Tayibnapis, Farida Yusuf (2008). Evaluation of Programs and Evaluation Instruments for Education and Research Programs. Jakarta: PT. Rineka Cipta.p.9

8. Menix, Kristi D. (2007). "Evaluation of Learning and Program Effectiveness". The Journal of Continuing Education in Nursing, Vol. 30, No.5. September/October.p.203

9. Miles, Mattew B dan A.Michael Huberman.(1994). Qualitative Data Analysis. New Delhi: Sage Publications.

10. Moeldoko. (2013). "The Use of TNI Forces to Achieve Integrated Tri Matra In Order to Guard Sovereignty of the Unitary State of the Republic of Indonesia", Patriot, Special Edition of the TNI Anniversary, October, p. 14

11. Newcomer, Kathryn E dan Harry P Hatry, Joseph SW Holey.(2010). Planning and designing useful evaluations", Hand Book of Practical Program Evaluation ,Third Edition. San Franscisco: Jossey Bass.p.5

12. Prabowo, J. Suryo. (2013). Komando Teritorial: Sebagai Bagian dari Gelar Kekuatan TNI AD, Jakarta: Pusat Pengkajian Strategi Nasional (PPSN), pp. 122-123

13. Rallis, Sharon F dan Bolland, Kathleen A. (2005). "What is Program Evaluation? Generating Knowledge for Improvement". Archival Science.Spring.Vol.4. 
14. Robson (2002) in Metcalfe, Sylvia A dan Mary Anne Aitken \& Clara L.Gaff. (2008) "The Importance of Program Evaluation: How Can it be Applied to Diverse Genetics Education Settings?". Journal Genet Counsel,Vol.17.p.171

15. Smith (1989) in Owen, John M (2006). Evaluation Fundamentals in Program Evaluation: Forms and Approaches, Third Edition. Crown Nest-NSW: Allen\&Unwin.pp.11-12

16. Song, Nick Letch.(2012). "Research on IT/IS Evaluation: A 25 Year Review Xingchen". Electronic Journal Information Sistem Evaluation. Volume 15 Issue 3

17. Stufflebeam, Daniel L dan Shinkfield, Anthony J.(2007). Evaluation Theory, Models \& Applications. San Franscisco: Jossey Bass.pp.4-8

18. Suhendra, Zulfi. (2014). It's The 5 Most Damaged Towns in Indonesia, http://finance.detik.com/read/2013/09/09/162903/2353549/1016/ini-dia-5-kota-terkumuh-di-indonesia, accessed on April 23, 2014 at 00:18 hrs

19. TNI Headquarters. (2012). General Plan TNI TMMD FY 2012. Jakarta: Operational Responsible TMMD.pp.35

20. Umar, Musni (2014), "Poverty in the Capital Increases", Daily Newspaper Seputar Indonesia, 22 April 2014 , p. 11

21. Vendung, Evert. Evaluation. (1997): A Semantic Magnet in Public Policy and Program Evaluation, Chapter 1. New Jersey: Transaction Publishers Rutgers.p.3

22. Weiss, C.H (1998). Evaluation, 2nd edition. Upper Saddle River: Prentice-Hall.p.4

23. Wheelen, Thomas L. dan Hunger, J.David. (2012). Concepts in Strategic management and business Policy: Toward Global Sustainability. New Jersey: Prentice-Hall,Inc.p.21

24. Wirawan. (2011), Evaluation: Theory, Model, Standard, Application and Profession. Jakarta, PT. Rajagrafindo Persada.p.17. 